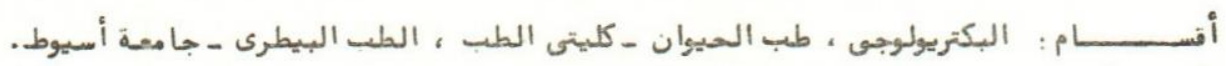

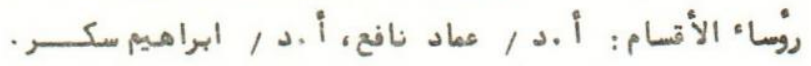

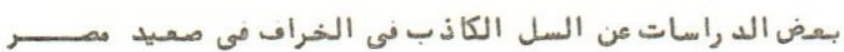

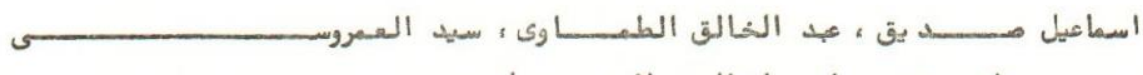

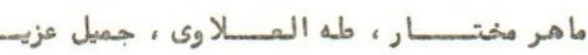

يعتبر مرض السل الكاذب موضا خطيرا بالنسبة للأغنام والماعز · وقد وجد أنه يسبب خسائر ماد حهـ

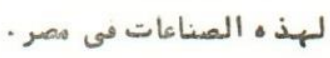

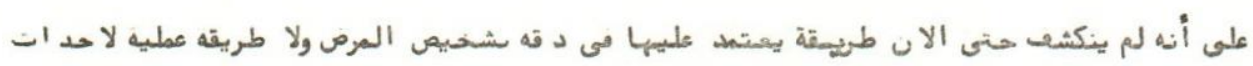

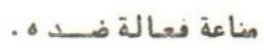

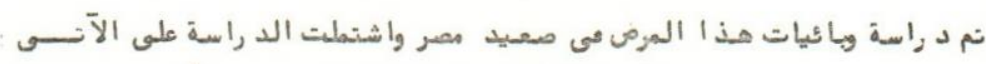

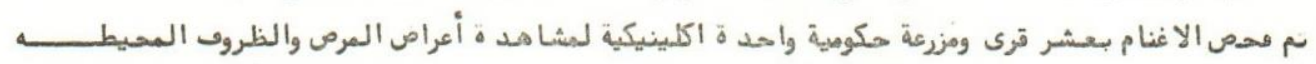

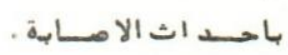

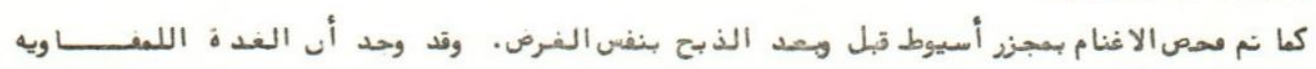

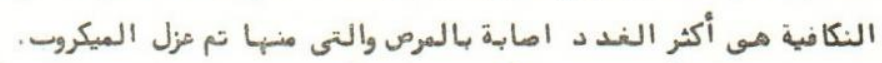

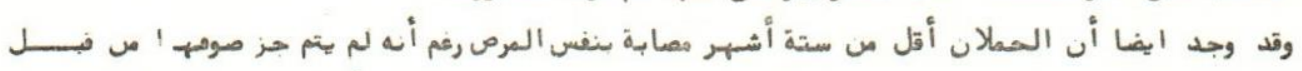

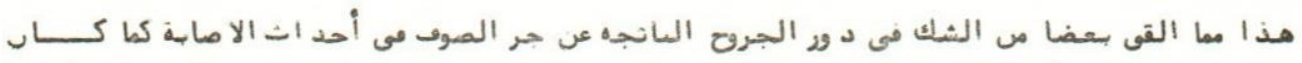

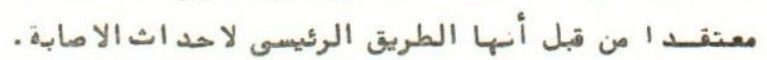

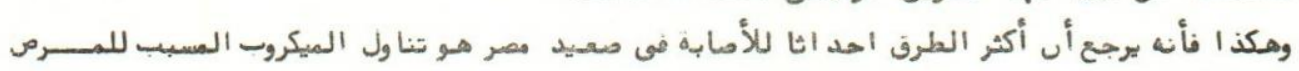

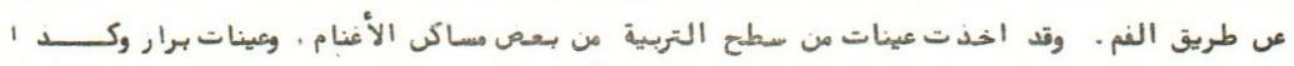

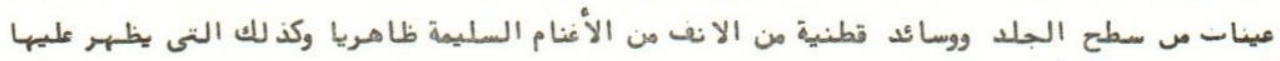

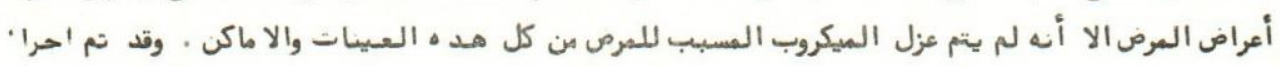

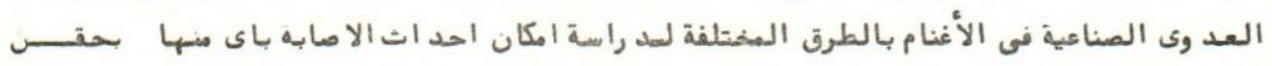

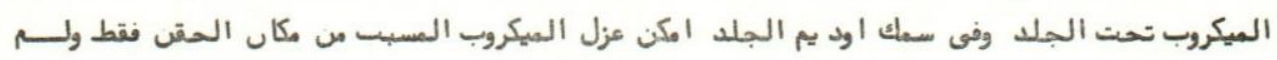

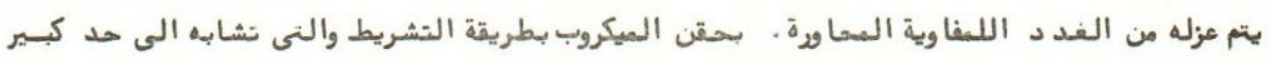

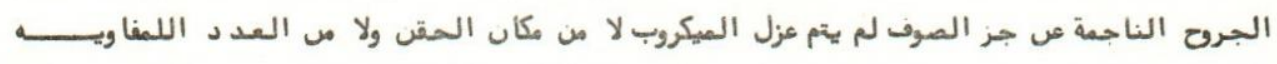

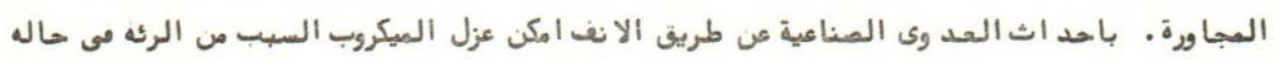

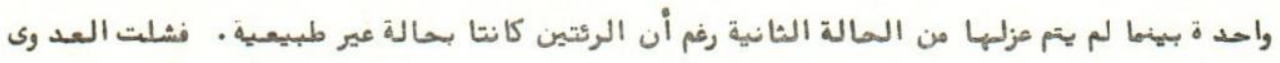

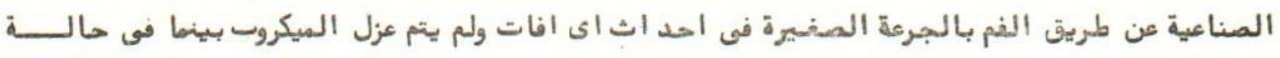

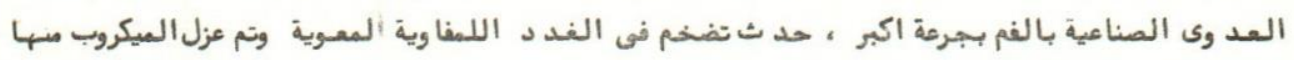

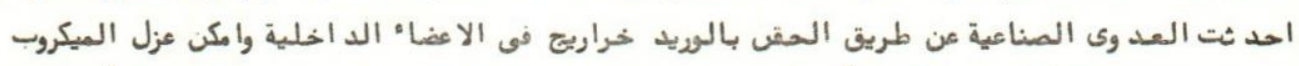

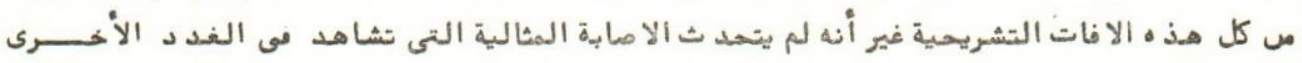

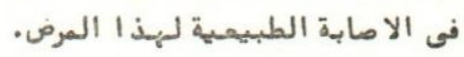


Dept. of Hicrobiology,

Faculty of Medicine, Assiut University,

Head Prof. Dr. E.K. Nabfie.

\title{
SOME STUDIES ON CASEOUS LYMPHADENITIS OF SHEEP IN UPPER EBYPT \\ (With 4 Tables)
}

\author{
I. SEDDIK, A,A, EL-TIMAWY, S, EL-AMROUSI\% M,M. ZAKI, T, EL-ALLAWY * \\ and $G, K, A Z I Z^{* * *}$ \\ (Received at $3 / 1 / 1982$ )
}

\begin{abstract}
SUMMARY
Caseous lymphadenitis is a serius disease of sheep and goats. Sheep from ten villages and one governmental parm in Assiut governorate were examined for clinical manifestation of the disease and the 1solation of the causative organism. Sheep from abattoir were also examined before and after slaughter for the same purpose. It was found that the parotid lymph node was the one that showed the highest percentage of infection. Moreover lambs below six months of age were found to be infected, although they were never been shown before. Ingestion was found to be the most predominant route of infection in Upper Egypt.Samples from surface soll of some sheep dwellings, faeces, surface skin and nasal swabs, from both apparently normal and clinically infected sheep failed to yield the Causative organism on culture. By experimental infection it was pound that both intradermal and S/C inoculation only yielded the organism from the inoculation site and failed to isolate the organism by scarification method. Oral dosing was negative to any lesions in case of small dose, However, a bigger dose resulted in enlargenent of mesentric lymph nodes and from which the organism was isolated. Intravenous inoculation produced lesions in parenchymatous organs, from which the organism was isolated.
\end{abstract}

\section{INTRODUCTION}

Caseuus lymphadenitis is an insidious chronic disease of sheep and goats, which is of considerable concern to animal breeding on a world wide basis.

The etiologic Pactor has for a long time been accepted to be Corynebacterium pseudotuberculosis (C. ovis) since it was isolated for the first time from diseased sheep.

In Egypt, caseous lymphadenitis was found to affect about $10 \%$ of the sheep population and would cause sever losses to sheep industry which was estimated to stand for ten million Egyptian pounds anually.

The causative organism, $\underline{\text { C.ovis }}$ was found to cause different disease syndromes in sheep, other than caseous lymphadenitis. In equines and bovines it causes ulcerative lymphangitis. In bovine; particularly the water buffalo, a severe disease syndrome was attributed to such infection to which the name "oedematous skin disease" was given locally.

The earliest 1solation of $\underline{C}$. ovis from sheep was done as early as 1891 by Preisz and Guinard. They 1 solated the organism; $\underline{c}$.ovis for the first time from sheep and related 1 t to caseous lymphadenitis. NOCARD and MOHLOR (1899) as well as CAREE and BIOGTEOU (1908) isolated the Prelsz-Nocard bacillus from affected sheep. They stated that it was Gram-positive diphtheroid capable of tissue invasion and production of powerful exotoxin.

Several authors thereafter (DAY, 1928, WOODROFF and GREFCRY, 1929; JEVET, 1930; HUNTER, 1933) 1solated C.. ovis from diseased sheep and gave an account of caseous lymphadenitis.

Concerning the lymph node distribution of caseous lymphadanitis, KARCH (1958) stated that the most commonly affected lymph nodes are prescapulars and prscrurals. Thereafter, mediastinals, bronchials and sublumbers. Finally dll nodes of body may be affected. SMITH and JONES (1961) gave the impression that lesions were formed in lung, and in lymph nodes, especially prescapular, prefermoral and mediastinal lymph nodes. JuBB and KONEEDY (1971) also stated that the superficlal nodes are only affected namely the prescapulars and precrurals belng mostly infected.

In lover Egypt, NADIM et al. (1966) polnted out that in slaughtered sheep bronch1als (31\%), mediastinals $(21.5 \%)$, subnaxillaries $(17.5 \%)$ and prescapulars (17.5\%) were mainiy found infected on meat inspection.

* neot. of Medicine \& Poultry Diseases, Faculty of Vet. Ned., Assiut University. * Dept. of Animal health care, Asslut Regional. 
In the experimental studies MAMID and LAKI (1973) artificially infected goat by $\underline{\mathrm{C}}$.ovis culture by both scarification and subcutaneous routes to study their immune response. The animals showed no clinical symptomo during the time of the experiment. Others tried the 1.v. route; CARNE (1973) used a dose of $5 \times 10^{8}$ with the result of abscess formation in lungs and kidneys and death of some sheep within three days. Other concentrations were used by $A D D O$ (1979) which amounted $4 \times 10^{8}$ with the aim of studying the pathology and bacteriology of abortion in experimentally infected ewes using $1 / V$ route.

In this work the distribution of infection in the lymph nodes in clinically infected animals and slaughtered sheep was studied. Some experimental studies were also tried, in order to clarify some aspects of the epizoot lology of the disease in Upper Egypt

\section{MATERIAL and METHODS}

1- Field cases: A total of 3822 sheep (768 under 6 months, 626 prom 6 months to 1 year, 698 from 1 to 2 years and 1730 over 2 years of age) from 10 villages and one governantal farn in Assiut Governorate were examined clinically. This examination included the palpation of the external superficial lymph nodes, prescapular, precrural, submaxillary, parotid, supramammary in females and superficial inguinal in males.

The following samples were collected from both clinically healthy and apparently infected sheep for labotory examination and diagnosis:

a- Swabs from nostrils.

b- Swabs fromhalrless areas of surface skin (Inner thigh).

c- Faecal pellets were secured in plastic bags.

d- Surface soil of some pens (sheep dwellings) were collected in plastic bags.

e- Swabs from lesions (abscessed lymph nodes or any other suppuracive lesions).

2- Slaughtered sheep: A total of 33 sheep ( 24 males \& 9 feamles) were examined at Assiut abattoir by antimortem and postmortem and postmortem examination. The pollowing samples were collected for bacteriological examination:

a- Superficial lymph nodes; prescapular, precrural, submaxillary, parotid, superficial inguimal in males and supramanmary in females.

b- Internal deeply seated lymph nodes that showed pathological lesions.

c- Swabs from any lesion in any organ.

3- Sheep for experimental infection: Fourteen 0sinl sheep 1 - 3 years of age from Assiut Province were selected and their history and source indicated no prevlous infection. These were divided into seven pairs and were used for experimental infection.

4- Laboratory animals for pathogenicity test: Guinea-pigs, each weighing 200 - 300 gram were used.

5- C.ovis culture for experimental infection: A virulent strain of C. ovis was obrained from the central laboratory of Animal Health Research Institute which was standardized in broth culture to contain $10^{19}$ per one milliltre.

6- Culture and test media used:

a- Serum broth.

b- Blood agar.

c- Peptone water.

d- Christensen's medium.

All these media were prepared and used according to CRUICKSHANK et al. (1975).

Procedures adopted for sampling and culturing:

I - Clinically normal sheep: The samples were taken as mentioned before.

II- Clinically Infected sheep:

The wool in the vicinity of the lesion was closely clipped, the area cleaned and disinfected by $5 \%$ tincture lodine. The swabs, were taken from inside the lesion after being incised under complete aseptic conditions.

These swabs were inoculated into MacCarteny's bottles containing serum broth. These bottles were incubated 
at $37^{\circ} \mathrm{C}$ for $48 \mathrm{hrs}$. and were subcultured on blood agar plates. Plates were then incubated por 24 to $48 \mathrm{hrs}$. and were checked for bacterial growth, and the bacterlal growth were identifled as follows:

1- Direct smears were made, Fixed, stained by Gram's method and were examined por morphology and staining reaction.

2- Cultural characters in serum broth and on blood agar were noted and studied.

3- The following biological tests were done:

a- Sugar fermentation of dextrose, sucrose, maltose, lactose and salicin.

b- Reaction on littius milk. c- Gelatin liquefaction.

d- Catalase test.

e- Urease test.

p- Pathogenicity test for guinea pigs by $S / C$ inoculation in the thigh region.

III- Slaughtered sheep:

The lymph nodes or lesions were scared by a heated spatwla and then opened under complete aseptic conditions and inoculated Into MacCartney's bottles contalning serum broth. Similar further procedures for culture, isolation and identification were carried out.

IV - Experimental infection of sheep:

The dose, route and site of inoculation of the seven pairs 0siml sheep are given: in Table 1 . The last pair (No. 7) was left as a control and was inoculated by different routes with peptone water only.

\section{RESULTS}

The clinical examination of 3822 sheep of different ages and sexes revealed the enlargement of lymph nodes of 167 heads (4.3\%) as shown in Table II. The percentage of clinically infected sheep, site of lesion and C.ovis isolation as well as other isolates were recorded qlso in Table II.

Table III revealed C.ovis isolation from lymph nodes of 33 clinically normal slaughtered sheep and site of isolation. The clinical manifestations and lesions of sheep experimentally infected with $\underline{c}$.ovis were recorded in Table IV.

\section{DISCUSSION}

In this study $\underline{\mathrm{C}}$. ovis was isolated from $20 \%$ os suckling lambs around six months of age which have never been shown before. This result agreed with the finding of MADDY (1953), who stated the possibility of isolation of C. ovis from four months old lambs.

The results of pathological findings before and after slaughtering sheep in this study showed that apparently normal sheep may harbour the organlsm. Culture of lymph nodes of slaughtered sheep (24 males and 9 females) resulted in the isolation of $\underline{C}$.ovis from one lung and one parotid iymph node of male individuals, while those of pemale did not reveal the presence of the organism. Consequently it can be stated safely that the actual incidence of $\underline{c}$.ovis infection should not be based only on the clinical examination of sheep since hidden latent infection may be overlocked on such examination. This constitutes a risk of the dissemination of the disease among heal thy sheep.

Up till now there are no rellable methods to reach an accurate diagnosis of latent infection, AWAD (1960), FARID and MAMOUD (1960), ZAKI (1968), SHIGIDI (1979) and BARAKAT et al. (1980).

Isolation of Staph. aureus, Strept. pyogenes and $\underline{\mathrm{C}}$.pyogenes from lymph nodes of clinically infected sheep were recorded in our research also RENSHAW et al. (1979) described cases from which they isolated other pyogenic organisms (‥pyogenes, $\underline{C}$.equi, Staph. aureus and Pseudomonas aeruginosa) in association with $\underline{\mathrm{C}}$.ovis.

Laboratory examination of various lymph nodes of sheep pointed out that the parotid lymph nodes showed the highest percentage of $\underline{c}$.ovis infection. NADIM et al. (1966) found that the bronchial and mediastinal lymph nodes showed the highest percentage of $\underline{C}$.ovis infectlon. 
I. SEDOIK, et al.

Experimental infection in this study was carried out by difierent methods, one of which by scarification of the skin in an area adfacent to the right submaxillary lymph nodes. After the lapse of 200 days the organisim was not recovered from the site of injection or the adfacent lymph node, which showed no abnormalities. Absence of infection by this route may threw some doubt on the role of shearing as a primary cause or way through which the causative organism may be introduced into the body.

Experimental intradermal infection resulted in the isolation of $\underline{c}$.ovis only from the site of inoculation where it formed only a local suppurative focus.

Intranasal infection in this study resulted in the isolation of $\underline{C}$.ovis from the lungs in one case, while in the other lung involvement without $\underline{C}$. ovis isolation was manifested. Oral infection entailed a relatively small dose of $\underline{\mathrm{c}}$.ovis culture $(10 \mathrm{mls}$. of $10 \mathrm{~m} / \mathrm{ml}$.) which may explain the reason of failiure to recover the organism from faeces, gut, and mesentric lymph nodes. This may be attributed to the lowered virulence of the organism so they produce no lesions or that the number of organisms in the inoculum was below that needed to initlate infection. CARNE (1932) stated that sheep experinentally infected by the oral route suffered from lesions which were confined to the lymph nodes draining the buccal cavity and that the organism was not recorded from caudal gut.

In the 2 nd experimental oral route, where a bigger dose of $\underline{c}$.ovis culture $(50 \mathrm{mls})$ was given, the possibility of intestinal infection was greater than small dose. The causative organism was recovered from the enlarged mesentric lymph nodes 200 days post infection similar to that reported by BELSCHNER (1959). Intravenous experimental infection of sheep with small $\underline{\mathrm{C}}$. ovis dose (1 ml.) resulted in abscess formation in the internal parenchymatous organs such as spleen, liver and lung as well as bronchial lymph nodes. $\underline{\text { covis }}$ was recovered on culturing the lesions produced. It appears therefore that caseous lymphadenitis might have a bacteraemic phase in which the organisms are desseminated to parenchymatous organs, were they colonize and set up infection.

\section{REFERENCES}

Addo, P.B. (1974): Pathology and Bacteriology of abortion in sheep experimentally infected with Corynebaoterlum pseudotuberculosis. Bull. Anim. Hlth. Prod. Afr. 27, 257.

Awad, F.I. (1960): Serological investigation of pseudotuberculosis in sheep. 1-agglutination test. Amer. J. Vet Res., 21, 251 .

Barakat, A.A. (1980): Immunlzation against caseous lymphadenitis of sheep using attenuated bovine tubercle bacillus of calmotte and Guerin (BCG.). Bull. Off. Int. Epiz., 91 (9-10), 679.

Belschner, H.G. (1959): Sheep Management and Disease. Angus and Robortson lst ed.

Carne, H.R. (1932): Caseous lymphadenitis: Ingestion as a method of infection of sheep with Proisz-Nocard bac111us. The growth of Preisz-Nocard bacillus in sheep faeces. J. Sci. and Indust. Res. Australla, $5,98$.

Caree, H. and Bigoteau, L. (1908): Cited by Abdel-Chapfar et al. (1966). Proceeding 7th Ann. Arab. Vet. Congr., pp 55.

Cruickshank, R.; Duguld, J.P.; Marmion, B.P. \& Swain, R.H.(1975): Medical Microbiology 12th ed., Vol. 2, Practice of Medical Microblology, 189-190.

Day, L. (1928): Skin lesion tuberculin reaction cattle. J.A.M.V.A. 19, 72.

Farid, A. \& Mahmoud, A.H. (1960/1961): Preliminary trials on the diagnosis of caseous lymphadentitis in Egypt by means of intradermal imoculation of allergic materlal. Vet. Med. Giza, $\underline{7}$ (7-8) 253.

Hamid, Y.M.A. \& Zaki, M.M. (1973): Viability of Corynebacterium ovis in animal dewzllings in different reasons.

J. Egypt. Vet. Med. Ass., 32, (3-4): 189.

Hunter, A.H. (1933): Cassous lymphaderitis, Results of 6 years observations. Vet. Rec. $13,952$.

Jewett, w. (1930): J. Comp. Path., 43, 109, Cited by Behhan et al. (1962). Vot. Bull., 32, (10), 645.

Jubb, K.V.P. \& Kennedy, P.O. (1971): Pathology of Domestic Aninals. N.Y. Academic Press.

Maddy, K.T. (1953); Caseous lymphodentitis of sheep. J. Amer. Med. Ass. 122: 257.

Marsh, H. (1958): Nowson's sheep D1seases. The William and Wilkins \& Com. U.S.A. 2nd ed.

Nadim, M.A.; Far1d, A. \& Mohmoud, A.H. (1966): Caseous lymphä́denitis in sheep in Egypt. 1- Lncidence affection and isolation of the causative, organism. 5. Arab. Vet. Med. Ass., 26, 67. 
Norgerd, V.A. and Mohler, J.R. (1899): Cited by Newson's sheep diseases, 1955. 3rd ed. Hadliegh Marsh, D.K.h., 87. Oas. Iymph.

Renshawy, H.W., Graff, V.P. \& Cates, N.L. (1979): Visceral caseous lymphadenitis in thin ewe syndrome: isolation of C.ovis, Staphylococci and Maraxella spp. from Internal abscesses in emaclated ewes. Am. J. Yet. Res. $40,8,1110$.

Shigidi, M.T.A. (1979): A comparison of five serological tests for the diagnosis of experionental C.ovis infection in sheep. Australlan Vet. J. 50, 537.

Smith, H.A. and Jones, Th. C (1961): Veterinary Hathology. 2nd ed. Lea \& Febiger Philadelphia, U.S.A.

woodruff. H.A. \& Gregory, ' S. (1929): Caseous lymphadenitis. II. Observations on the age and sex incidence In an infected lock in relation to possible routes of infection. Australian Vet. 3. 5, 134.

Lak1, M.M. (1968): The application of a new technique for diagnosis of C.ovis infection. Res. Vet. Sci. 9 , 489.

rable (I): Experimental infection of sheep by $\underline{\text { C.ovis culture }}$

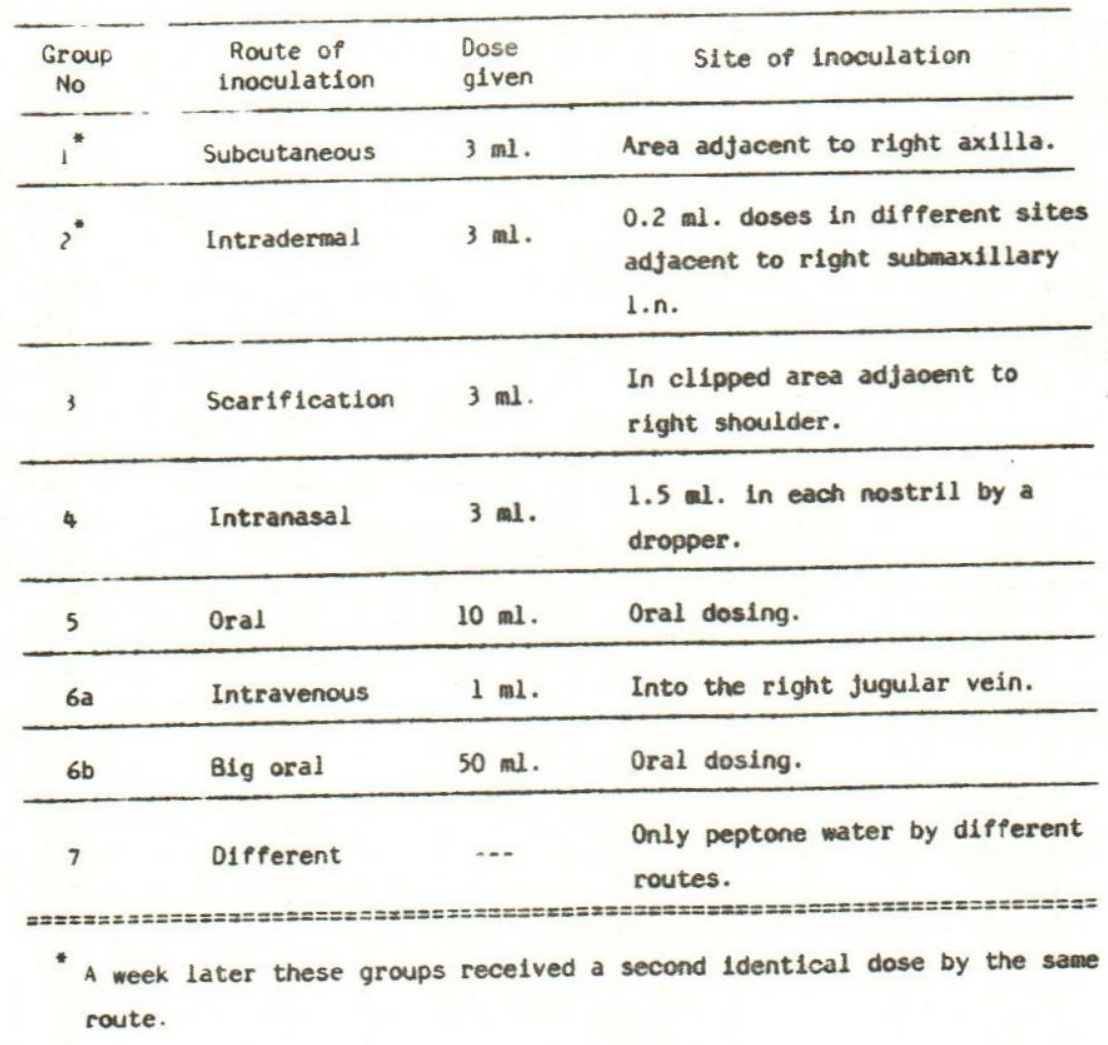




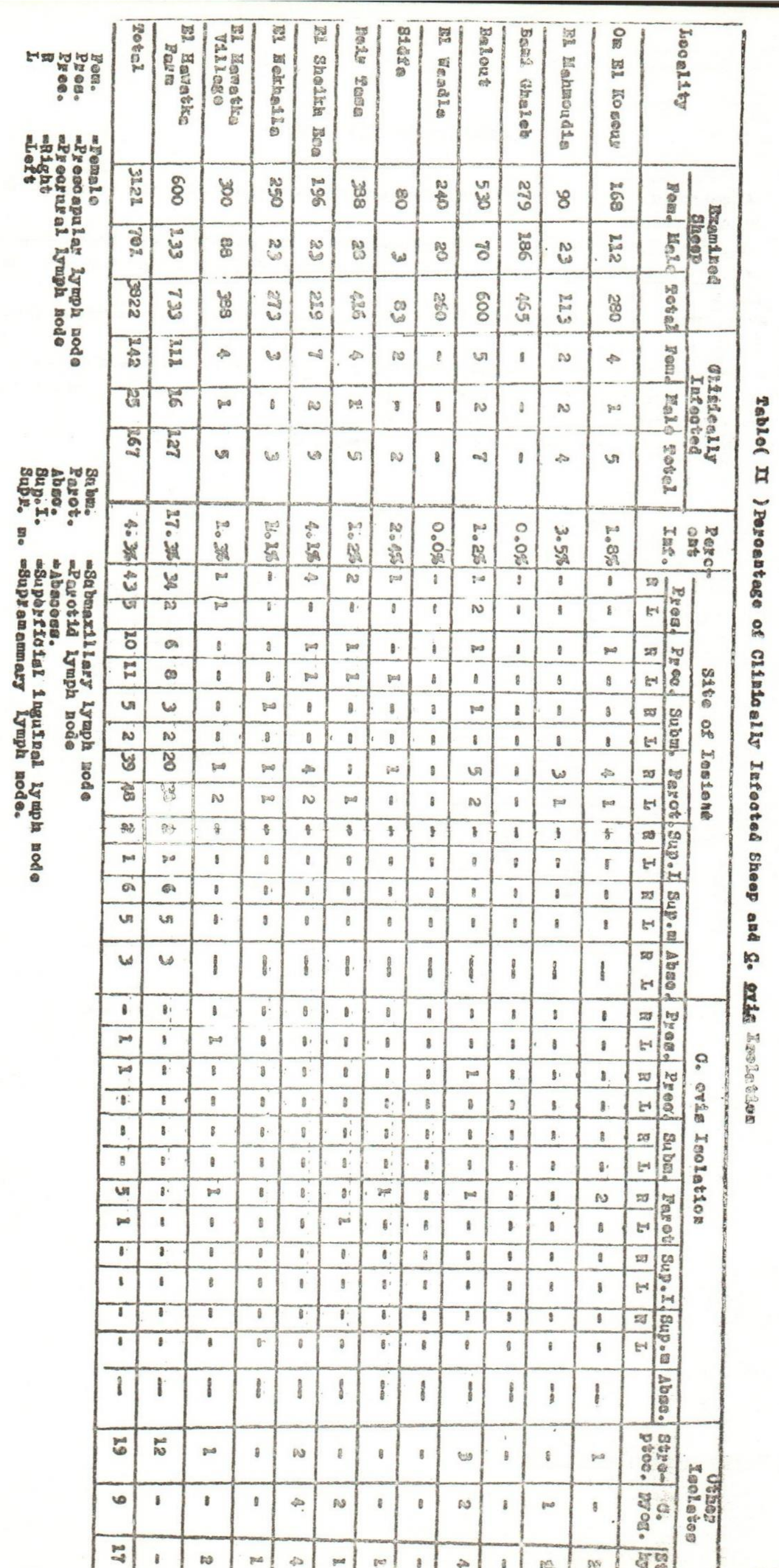


CASEOUS LYMPHADENITIS OF SHEEP

Table (III)

Isolation of $\underline{C}$.ovis from Lymph Nodes Clinically Normal Slaughterd Sheep

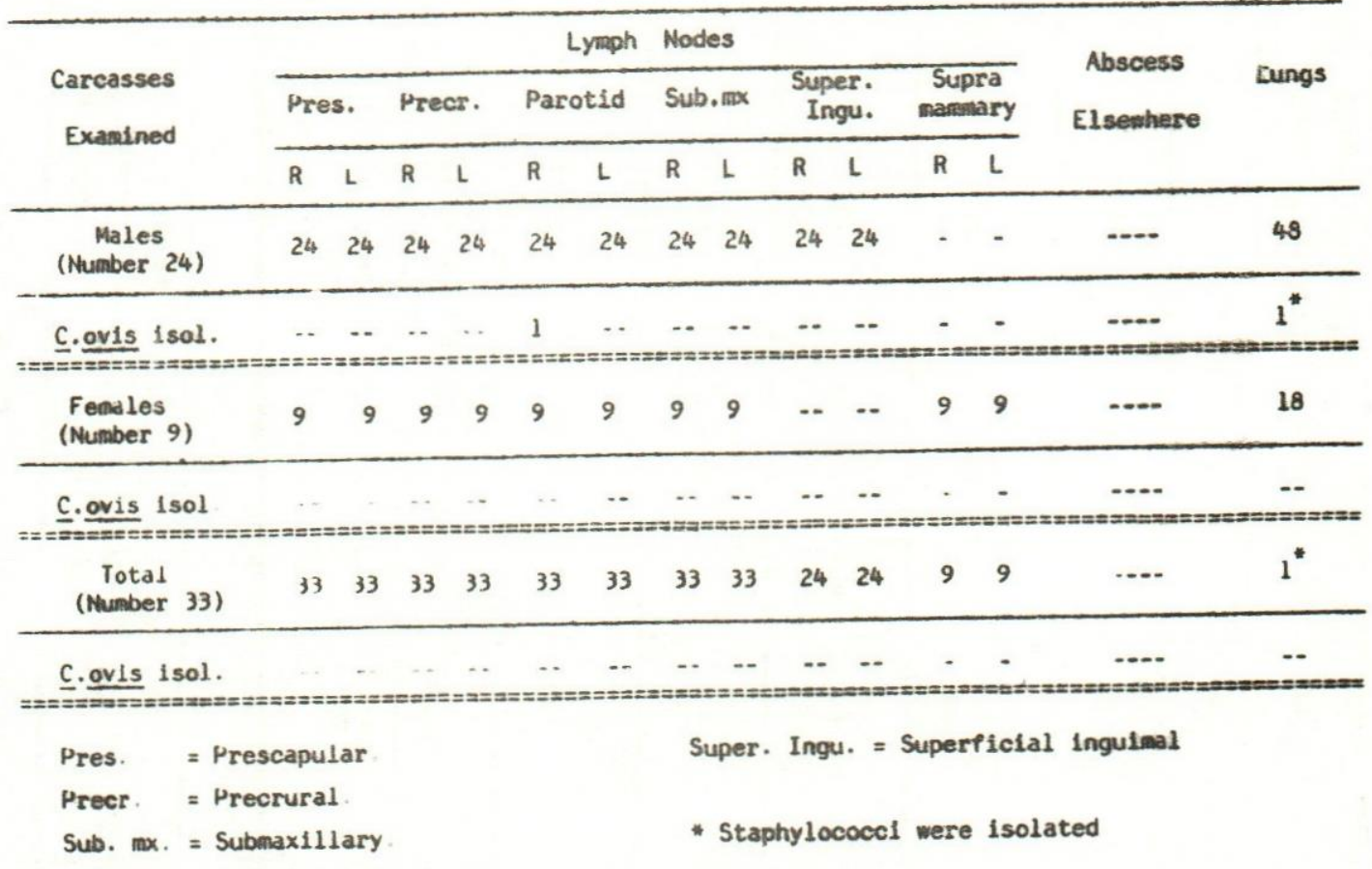

Assiut Vet.Med.J.Vol. 11, No. 21, 1983. 


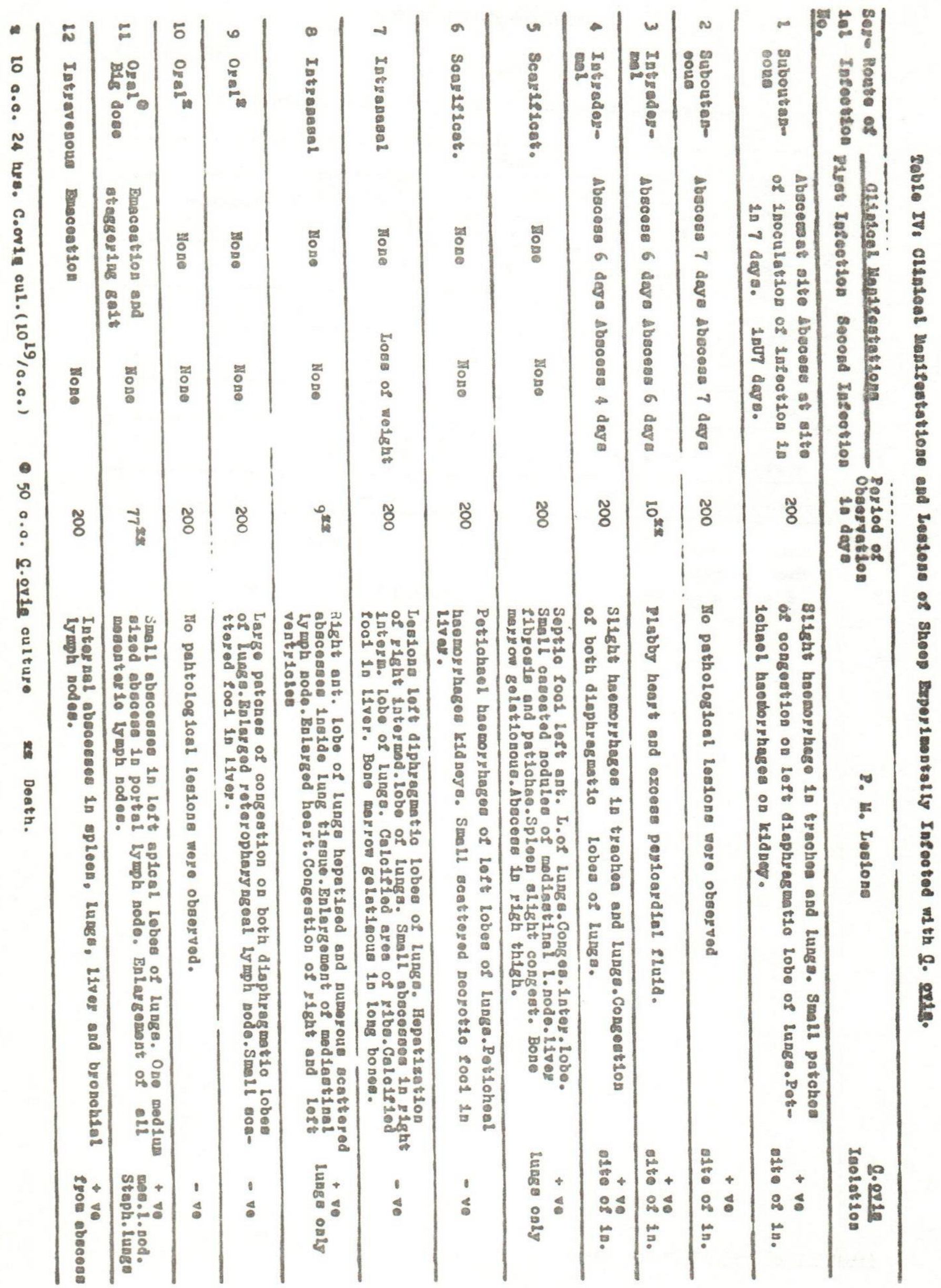

